\title{
Mangiferin ve Kanser
}

\section{Mangiferin and Cancer}

\section{Fatmanur Hümeyra Zengin ${ }^{1}$, Gamze Akbulut ${ }^{2}$}

Geliş tarihi/Received: 24.04.2018 • Kabul tarihi/Accepted: 12.01.2019

\section{ÖZET}

Kanser, kontrolsüz ve anormal hücre çoğalması ile karakterize bir hastalıktır. Birçok yeni antikanser ilacı piyasada bulunmasına rağmen, çoğu zayıf biyoyararlanım, yüksek maliyet ve amaçlanmayan yan etkilerden dolayı hayati endişelere neden olmaktadır. Bu nedenle kanserin başka yöntemlerle önlenmesi düşüncesi ortaya atılmış ve "kemoprevensiyon" son ylllarda üzerinde en fazla çalışılan konulardan biri olmuştur. Mango olarak da bilinen Mangifera indica, uzun yıllardır Ayurveda ve geleneksel tıbbi sistemlerde kullanılmaktadır. Mangonun ana etken maddesi kabul edilen mangiferin, C-glukozilksanton yapıda çeşitli farmakolojik aktivitelere sahip, doğal bir polifenoldür. Son yıllarda yapılan çalışmalarda, mangiferinin antiinflamatuvar, antikanser, antidiyabetik, antioksidatif, yaşlanma karşıtı, immünomodülatör, hepatoprotektif, antihiperlipidemik, antialerjik ve analjezik etkiler gibi özelliklere sahip, umut verici bir antioksidan olduğu bildirilmiştir. In vitro ve in vivo çalışmalarda farklı kanser tiplerine karşı geniş spektrumlu etkililik göstermektedir. Mangiferinin yapısındaki C-glukozil bağ ve polihidroksi grupları, temel olarak serbest radikal temizleme etkinliğine katkıda bulunur. Ayrıca proinflamatuvar transkripsiyon etmenleri, hücre döngüsü proteinleri, büyüme faktörleri, kinazlar, sitokinler, kemokinler, adhezyon molekülleri ve inflamatuvar enzimleri modüle etme yeteneğine sahip olduğu gösterilmiştir. $\mathrm{Bu}$ hedefler potansiyel olarak kanserin başlatılması, ilerlemesi ve metastazını baskılayarak mangiferinin kemoprevensiyon ve tedavi edici etkilerine aracılık edebilir. Ancak, çalışmalarda mangiferinin oral biyoyararlılığının çok düşük olduğu bildirilmiş ve etkileri üzerine bildirilen çalışmalar ağırlıklı olarak kültür hücrelerinde ve kemirgenlerde yürütülmüştür. Mangiferinin daha iyi anlaşılabilmesi için insanlarda daha fazla klinik çalışmaya gerek vardır.

Anahtar kelimeler: Mangiferin, kanser, antioksidan

\section{ABSTRACT}

Cancer is a disease characterized by uncontrolled and abnormal cell proliferation. Although many new anticancer drugs are found in the market, most are causing vital concerns due to poor bioavailability, high cost and unintended side effects. For this reason, the idea of preventing cancer by other methods has been put forward and "chemoprevention" has become one of the most studied topics in recent years. Mangifera indica, also known as mango, is used for Ayurveda and traditional medical systems, for long years. Mangiferin, the main active ingredient of mango, is a natural polyphenol with various pharmacological activities in its C-glucoxanthone structure. In recent years studies; mangiferin has been reported to be a promising antioxidant with properties such as antiinflammatory, anticancer, antidiabetic, antioxidative, antiaging, immunomodulatory, hepatoprotective, antihyperlipidemic, antiallergic and analgesic effects. In vitro and in vivo studies

1. İletişim/Correspondence: Ankara Eğitim ve Araştırma Hastanesi, Beslenme ve Diyet Bölümü, Ankara, Türkiye • E-posta: humeyrazengin@hotmail.com (1) https://orcid.org/0000-0003-1586-5878
2. Gazi Üniversitesi Sağlık Bilimleri Fakültesi, Beslenme ve Diyetetik Bölümü, Ankara, Türkiye (D) https://orcid.org/0000-0003-0197-1573 
show broad spectrum efficacy against different types of cancer. The C-glucosyl bond and polyhydroxy groups of the mangiferin structure are mainly responsible for the free radical cleansing activity. It has also been shown to have the ability to modulate proinflammatory transcription factors, cell cycle proteins, growth factors, kinases, cytokines, chemokines, adhesion molecules and inflammatory enzymes. These targets may potentially mediate chemoprevention and therapeutic effects of mangiferin by inhibiting the initiation, progression and metastasis of cancer. However, studies have reported that the oral bioavailability of mangiferin is very low, and the studies reported on their efficacy are predominantly carried out in culture cells and rodents. More clinical trials are needed in humans for better understanding of mangiferin.

Keywords: Mangiferin, cancer, antioxidant

\section{GİRIŞ}

Kanser, kontrolsüz ve anormal hücre çoğalması ile karakterize bir hastalıktır. Hücre çoğalması kontrol edilmezse ölümle sonuçlanabilir. Kansere tütün, bulaşıcı organizmalar ve sağlıksız bir diyet gibi dış etmenler ve genetik mutasyonlar, hormonlar ve bağışıklık durumu gibi iç etmenler neden olabilir (1). Uluslararası Kanser Araştırmaları Ajansı, 2000 yılında 10 milyon kanser vakası olduğunu ve altı milyon kişinin kanser nedeniyle öldüğünü, 2012 yılında ise bu rakamin 14 milyon kanser vakasına ve 8.2 milyondan fazla kanser nedeniyle ölüme ulaştığını bildirmiştir (2). Birçok yeni antikanser ilacı piyasada bulunmasına rağmen, çoğu zayıf biyoyararlanım, yüksek maliyet ve amaçlanmayan yan etkilerden dolayı hayati endişelere neden olmaktadır. Bu nedenle kanserin başka yöntemlerle önlenmesi düşüncesi ortaya atılmış ve "kemoprevensiyon" son ylllarda üzerinde en fazla çalışılan konulardan biri olmuştur. Kemoprevensiyon (kimyasal önleme), kanserin oluşumunu veya ilerlemesini önlemek için doğal veya yapay maddelerin kullanımı olarak tanımlanır. Sebze ve meyvelerde bulunan kemopreventif kabul edilebilen fenolik bileşiklerin kanser istilası ve metastaz üzerinde potansiyel bir önleyici etkisi olabileceğine dair kanıtlar bilimsel literatürde gittikçe artmaktadır (3,4). Mango olarak da bilinen Mangifera indica (Anacardiaceae), uzun yıllardır Ayurveda ve geleneksel tıbbi sistemlerde kullanılmaktadır. Mango, Anacardiaceae ve çiçekli bitki familyasında yaklaşık 30 tür tropikal meyve ağacından oluşan mangifera cinsine ait bir bitkidir (5). Mangonun ana etken maddesi kabul edilen mangiferin, C-glikosilksanton yapıda çeşitli farmakolojik aktivitelere sahip doğal bir polifenoldür (6). En önemli kaynağı mango ağacı olmakla birlikte, mangiferin, şifalı ve koruyucu özellikleri olan bazı şifalı bitkilerde ve Güney Afrika'da popüler bir bitki çayı olan honeybush'da (Cyclopia sp.) da bulunur. Son ylllarda yapilan çalışmalarda, mangiferinin antiinflamatuvar (7), antikanser (8), antidiyabetik (9), antioksidatif, yaşlanma karşıtı, immünomodülatör, hepatoprotektif (10) antihiperlipidemik (11), antialerjik (12) ve analjezik etkiler gibi özelliklere sahip, umut verici bir antioksidan olduğu bildirilmiştir $(5,13,14)$. Bu derlemede, mangiferinin antikanser etkisi ve altında yatan mekanizmalar incelenmektedir.

\section{Mangiferinin Kimyasal Yapısı}

Mangiferin, ilkkez Wiechowski tarafindan tanımlanan Mangifera indica'nın çeşitli bölümlerinde mevcut olduğu bildirilen bir glikoksantondur. Mangiferinin kimyasal yapısı, 1,3,6,7-tetrahidroksitanton-C2- $\beta$-Dglukozit olarak bildirilmiştir (Şekil 1 ve 2) (15).

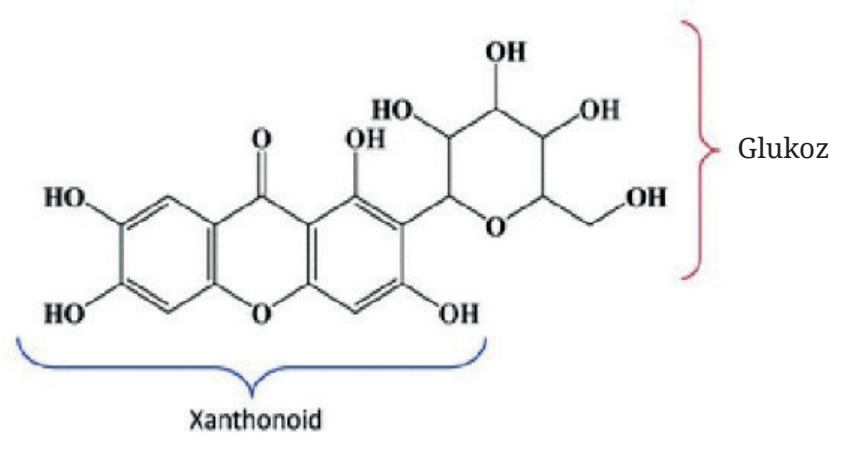

Şekil 1. Mangiferinin kimyasal yapısı 


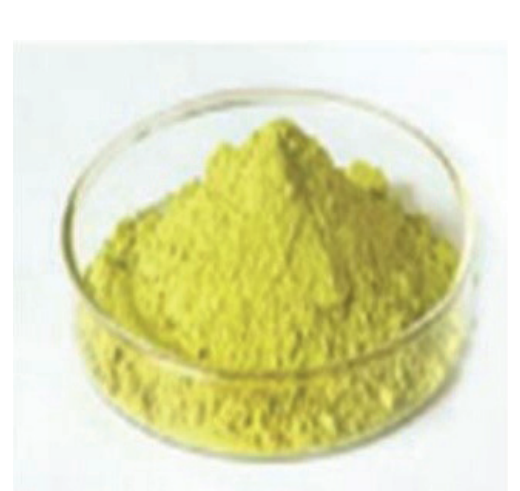

Şekil 2. Mangiferin tozu

Mangiferin suda iyi çözünmekte, bu yüzden kolaylıkla demleme ve kaynatmayla infüze edilebilmektedir (16). Ksanton yapıdadır ve ksantonlar ısıya dayanıklı moleküllerdir. Ayrıca ksantonlar, bilinen en güçlü antioksidanlardandır, hem C, hem de E vitamininden dahagüçlüolduklarıdüşünülürvesüperantioksidanlar olarak da ifadelendirilir (17). Mangiferin molekülündeki, dört aromatik hidroksil grubu, güçlü anti-radikal ve antioksidan özelliklerinin nedeni olarak gösterilmektedir (16). Mangonun kabuğunda, meyvelerinde, köklerinde ve yapraklarında bulunan farmakolojik olarak aktif bir fitokimyasal ve doğal bir polifenolik antioksidandır (14,17). Mangiferinin biyotransformasyonu sonucunda norathyriol dahil olmak üzere yaklaşık 40 metaboliti rapor edilmiştir, ancak biyolojik aktivite için spesifik bir metabolit tanımlanmamıştır (18). Mangiferin ve mango ekstresi üzerinde yapılan araştırmalarda farmakolojik değerlendirme, mangonun başlıca kimyasal bileşeni olan mangiferinin mango özütü tarafından sergilenenlere benzer farmakolojik aktiviteler sergilediğini ortaya koymaktadır (19).

\section{Mangiferinin Kanser Üzerine Etkisi}

Son yıllarda birçok tıbbi bitkiden izole edilen polifenollerin, çeşitli hastalıkların önlenmesi ve tedavisinde belirgin bir role sahip olduğu düşünülmektedir. Çalışmalarda polifenollerin inflamasyon tepkilerini modüle ettiği ve karsinogenezi zayıflattığı gösterilmiştir $(8,20)$. Uzun yıllardır geleneksel tıbbi tedavi olarak kullanılmakta olan ve üzerine birçok araştırma yapılmış bir polifenol olan mangiferin çeşitli kanser türlerine karşı kemopreventif bir madde olarak ilgi çekmektedir. In vitro ve in vivo çalışmalarda farklı kanser tiplerine karşı geniş spektrumlu etkililik gösterdiği bildirilmiştir. Mangiferinin yapısındaki C-glukozil bağ ve polihidroksi grupları, temel olarak serbest radikal temizleme etkinliğine katkıda bulunur. Ayrıca proinflamatuvar transkripsiyon etmenleri, hücre döngüsü proteinleri, büyüme faktörleri, kinazlar, sitokinler, kemokinler, adhezyon molekülleri ve inflamatuvar enzimleri modüle etme yeteneğine sahip olduğu gösterilmiştir. Bu hedefler potansiyel olarak kanserin başlatılması, ilerlemesi ve metastazını baskllayarak mangiferinin kemoprevensiyon ve tedavi edici etkilerine aracılık edebilir $(6,18,19)$. Mangiferinin kanser üzerindeki olası mekanizmaları özetlenmiştir (Şekil 3).

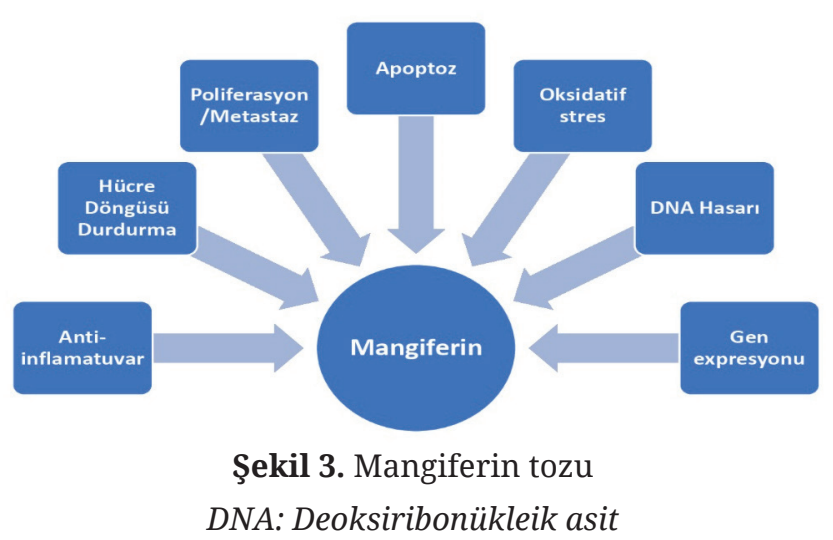

Antiinflamatuvar: Kronik inflamasyon kanserin oluşumuna neden olan önemli nedenlerden biridir. Kanserlerin yaklaşık \%20'si bakteriyel veya viral enfeksiyonlar, otoimmün hastalıklar ile indüklenen kronik inflamasyondan kaynaklanmaktadır. Kronik inflamasyon, olumlu bir ortam sağlayarak, tümörlü hücre büyümesini ve hayatta kalmasını artırabilir (6). Geçmiş literatür bulguları, transkripsiyon faktörü nükleer faktör kappa B (NF-кB) ve transkripsiyon protein 3 aktivatörün (STAT3) çeşitli kanser hücrelerinde kurgusal olarak ortaya çıktığını ve hücre büyümesi, hücre adhezyonu, apoptoz, farklılaşma, inflamasyon, oksidatif stres tepkileri ve immün yanıtta kritik rol oynadığını göstermiştir (21). Mangiferin, antiinflamatuvar, antioksidan 
ve antiviral etkiler gösterdiği bilinen bir polifenol olmasına rağmen, bu etkilerin altında yatan moleküler mekanizma tam olarak tanımlanmamıştır. Ancak, NF-кB aktivasyonunu modüle ederek inflamasyonu azaltabileceği düşünülmektedir (13). Sahoo ve arkadaşlarının (22) yaptığı bir çalışmadai Mangiferinin, reaktif oksijen türlerini inhibisyon yoluyla tümör nekroz faktörü (TNF), lizopolisakkarit (LPS), forbol-12-miristat-13-asetat (PMA) veya hidrojen peroksit $\left(\mathrm{H}_{2} \mathrm{O}_{2}\right)$ aracılı NF-kB aktivasyonunu baskıladığı bildirilmiştir. Multiple myeloma (MM) hücrelerinde mangiferin kaynaklı apoptozun altında yatan mekanizmanın incelendiği bir çalışmada da, mangiferin fosforile NF- $\kappa B$-indükleyici kinaz (NIK) ekspresyonunu azaltarak NF-кB'yi baskılamış ve

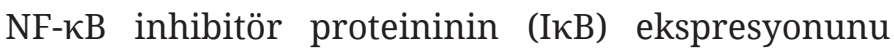
arttırmıştır. Ayrıca, mangiferinin, düzeye bağlı olarak MM hücrelerinin canlılığını azalttığı, kaspaz-3 aktivasyonu arttırdığı gözlemlenmiştir (23). Helicobacter pylori ile enfekte edilmiş insan gastrik adenokarsinoma (AGS) hücrelerinin $100 \mu$ g mangiferin ile birlikte kültürlendiği bir araştırmada ise, NF-кB altbirim p65, interlökinler-1 $\beta$, interlökin-8 (IL-8) ve TNF-a gibi inflamatuvar belirteçler mangiferin ile tedavi edildiğinde belirgin olarak bastırılmıştır. Buna ek olarak, siklooksijenaz-2 (COX-2) ve indüklenebilir nitrik oksit sentaz (iNOS) gibi inflamatuvar enzimlerin ekspresyonu, mangiferin eklenen AGS hücrelerinde belirgin şekilde azalmıştır (24).

Hücre döngüsünü durdurma: Normal bir hücre döngüsünün korunması, hücre homeostazı için önemlidir. $\mathrm{Bu}$ durum, hücrelerin kaybedildikleri oranda yenilenmesine izin vermektedir. Genellikle kanserde hücre döngüsü süresi azalarak habis hücrelerin anormal çoğalması artmaktadır. Mangiferinin mitojen aktive protein kinaz (MAPK) yolağını ve $G_{2} / M$ kontrol noktasından ilerlemeyi etkileyerek, daha normal bir hücre döngüsü süresi veya uygun kontrol noktasında hücre döngüsü arrestini sürdürdüğü düşünülmektedir (6). Yapılan bir çalışmada mangiferinin A549 insan akciğer adenokarsinoma hücreleri üzerine etkisinin incelenmesi sonucunda, siklin bağımlı kinaz 1-siklin
$\mathrm{B}_{1}$ (cdc2-siklin $\mathrm{B}_{1}$ ) sinyal yolunu aşağı regüle ederek $\mathrm{G}_{2} / \mathrm{M}$ faz hücre döngüsü arrestini tetiklediği ve protein kinaz C-NF-кB yolunu baskılayarak apoptotik hücre ölümünü uyardığı bildirilmiştir (25). Ultraviyole (UV) kaynaklı cilt kanseri üzerine norathyriol'ün etkisinin incelendiği bir diğer çalışmada, norathyriol, ekstraselüler sinyal düzenleyici kinaz (ERK1/2) kinaz aktivitelerini baskılamış ve UV'nin neden olduğu MAPK kaskadlarının fosforilasyonunu zayıflatmıştır. Norathyriol, fare deri epidermal JB6 P+ hücrelerinde hücre büyümesini, $G_{2} / M$ faz arrestini indükleyerek baskılamıştır. Fare deri tümörogenesis verileri, norathyriol ile yapılan tedavinin güneş UV ile indüklenen deri kanseri oluşumunu in vivo olarak önemli ölçüde azalttığını açıkça göstermiştir. Sonuçlar aynı zamanda norathyriolün, UV kaynaklı deri kanseri oluşumunda ERK' leri hedefleyerek transkripsiyon faktörü kompleksi aktivatör-1 (AP-1) ve NF-кB’nin inhibisyonu yoluyla güçlü bir kemoprevensiyon etkinlik sergilediğini bildirmiştir (26).

Poliferasyon/metastaz: Artmış poliferasyonun, tümörlerin çoğunun oluşumunun altında yatan temel mekanizma olduğu düşünülmektedir. Kanserin geç evrelerinde metastaz yaygindır ve hastaların başlıca ölüm nedenidir. Mangiferenin $(0,10,20$ ve $40 \mu \mathrm{M})$ PC3 prostat kanser hücrelerinin proliferasyonu üzerine potansiyel etkilerini araştırmak için yapılan bir çalışmada, mangiferin PC3 hücrelerinin proliferasyonunu düzeye bağlı bir şekilde baskılamıştır. PC3 hücreleri, 72 saat süreyle $20 \mu \mathrm{M}$ düzeyde mangiferin ile veya 48 veya 72 saat süreyle $40 \mu \mathrm{M}$ düzeyinde mangiferin ile muamele edildiğinde, PC3 hücrelerinin poliferasyonu kontrol grubuna göre önemli ölçüde azalmıştır. Ayrıca bu etki, B-hücre lenfoma geninin (Bcl-2) ekspresyon düzeylerinin azalması ve mikroRNA-182'nin (miRNA-182) ekspresyon düzeylerinin artması ile korelasyon göstermiştir (27). Cuccioloni et al. (28) yaptığı bir çalışmada, mangiferinin kolestrol homeostazı, protein döngüsü ve hücre adhezyonunu düzenlemekten sorumlu üç enzimi, (3-hidroksi 3-metilglutaril koenzim A redüktaz, proteazom ve plazminin) modüle ederek meme adenokarsinoması 
hücre poliferasyonunu baskıladığı bildirilmiştir. Mangiferinin antikanser aktivitesinin in vitro ve in vivo modellerde değerlendirildiği çalışmada ise, matriks metalloproteinaz-7 (MMP) ve 9'un düşük ekspresyonu ve $\beta$-katenin yolağının aktivasyonunun baskılaması yoluyla mangiferinin meme kanseri hücrelerinde hücre canlılığı ve metastazın baskılanmasına neden olduğu gösterilmiştir (29). $\mathrm{Bu}$ sonuçlar, mangiferinin doğal olarak oluşan bir kemoprevensiyon madde olma potansiyeline sahip olduğunu düşündürmektedir.

Apoptoz: Kanser hücrelerinin hayatta kalması ve çoğalabilmesi için, apoptozdan kaçınmaları gereklidir. Notch sinyal yolağının, hücre farklılaşması, çoğalması ve apoptozu kontrol etmede önemli bir rolü vardır (30). Mangiferinin Notch sinyal yolağını etkileyerek ve NF-kB aktivasyonu ile apoptozu etkilediği düşünülmektedir. Mangiferinin over karsinoma hücreleri (OVCAR3) üzerindeki etkisinin incelendiği bir çalışmada OVCAR3 hücrelerinin canlılığını önemli derecede baskıladığı, kaspaza bağımlı apoptozu aktive ettiği, belirgin bir şekilde Notch ekspresyonunu azalttığı bildirilmiştir (31). Yapılan bir diğer çalışmada sonuçlar beş farklı düzeyde mangiferinin (25-200 mikromol/L) doz bağımlı ve zaman bağımlı olarak lösemi hücrelerini (K562) çoğalmasını baskıladığını ve K562 hücrelerinde apoptozu indüklediğini göstermiştir. Mangiferinin BCR/ABL gen ekspresyonunun azaltılması yoluyla K562 hücrelerinde apoptozu indüklediği saptanmıştır (32). İnsan miyeloid lösemi hücresi HL-60'da mangiferin kaynaklı apoptozun mekanizmasını araştırıldığı bir çalışmada ise, mangiferinin apoptozu indüklediği, kaspaz-3 aktivitesinde ve DNA parçalanmasında eş zamanlı bir artışa neden olduğu, apoptotik indüksiyon sırasında ortaya çıkan sağkalım sinyallerinin incelenmesinde mangiferinin NF- $\mathrm{kB}$ p65'de azalmaya neden olduğu gözlemlenmiştir. Mangiferin, ayrıca Bcl-xL ve X-ilişkili apoptoz baskılayıcı protein (XIAP) expresyonunu bastırmıştır. $\mathrm{Bu}$ sonuçlar mangiferinin, NF- $\kappa \mathrm{B}$ aktivasyonunu ve Bcl-xL ve XAIP ekspresyonlarını baskılayarak, apoptozu indüklediğini göstermektedir (33).
Oksidatif stres: Hücre içi reaktif oksijen türleri (ROS)'nin uygun düzeyinin korunması, redoks dengesinin korunması ve hücresel çoğalmanın sinyalizasyonunda önemlidir. Bununla birlikte, ROS’un aşırı üretimi veya hücrelerden ROS'u ortadan kaldırmak için hücresel kabiliyetin bastırılması, hücre içi ROS’un önemli bir artışıyla, yani oksidatif stresle sonuçlanır ve özellikle DNA, lipitler ve proteinler için hücresel hasara neden olur. ROS stresi şiddetli ve kalıcıysa, bu zararlar sonuçta hücre ölümüne neden olabilir ve kanser riskini arttırabilir. Kanser hücreleri intrinsik artmış oksidatif stres altında olup, serbest radikal kaynaklı apoptoza karşı savunmasızdır (34). Yapılan çalışmalarda mangonun kabuk ve yapraklarında yüksek düzeyde saptanan mangiferinin, son derece güçlü bir antioksidan kapasite gösterdiği bulunmuştur $(11,34)$. Yapılan bir diğer çalışmada tüm düzeylerde, mangiferin, laskorbik asit (Vc) veya Trolox’tan daha yüksek radikal süpürme kapasitesine sahip olduğu bulunmuştur (35). Mangiferinin, insan nevroblastoması hücre dizisi (IMR-32) kullanılarak metilurum (MeHg) kaynaklı nörotoksisiteye karşı koruma kabiliyetinin araştırıldığı çalışmada, Mangiferin glutatyon (GSH) ve glutatyon-S-transferaz (GST) düzeylerinde artışa, malondialdehit oluşumunda azalmaya neden olmuştur. Serbest radikal temizleme kabiliyeti nedeniyle, oksidatif stresi azaltarak MeHg kaynaklı toksisiteye karşı koruyucu etki göstermiştir (36). Mangiferinin civa kaynaklı toksisite oluşturulmuş insan hepatoselüler karsinoma $\left(\mathrm{HepG}_{2}\right)$ hücreleri üzerindeki etkisi incelendiği çalışmada da, 50 $\mu \mathrm{M}$ mangiferin $\mathrm{HepG}_{2}$ hücrelerinin sağkalımını ve apoptozu arttırmış ve ROS türlerini anlamlı derecede azaltmıştır. GSH, GST, süperoksit dismutaz ve katalaz düzeylerinde civa kaynaklı azalmayı azalmıştır (37). Ayrıca mangiferin metalleri şelatlama yeteneğine sahiptir ve demir şelatlama yeteneğinden dolayı Fenton tipi reaksiyonlarda hidroksil radikal oluşumunu engeller (16,35).

DNA hasarı: DNA hasarına hassasiyet, mutasyon insidansını artırır ve kanser gelişimine neden olabilir. Bir polifenol olan mangiferin, antioksidan 
özellikler sergileyerek ve ROS'u azaltarak DNA hasarını azaltma eğilimi gösterir (38). Yapılan bir çalışmada insan göbek kordonu kanından izole edilmiş mononükleer hücrelerde (MNC) etoposit ile DNA hasarı oluşturulmuştur. $50 \mu \mathrm{M}$ mangiferin uygulaması nükleer faktör eritroid-2 (NF-E2) ilişkili faktör 2 (Nrf2) sinyalini aktive etmiş, NAD(P) H:ubikuinonoksido redüktaz (NQO1) ekspresyonu arttırmış ve MNC’lerdeki DNA hasarını önemli ölçüde azaltmıştır (39). İnsan lenfosit ve lenfoblastoid hücrelerinde radyasyona bağlı DNA hasarı üzerine mangiferinin etkisinin incelendiği bir diğer çalışmada ise, mangiferinin (5-25 $\mu \mathrm{g} / \mathrm{mL})$ insan lenfosit ve lenfoblastoid hücrelerini gama- ışınlarına bağlı DNA hasarına karşı koruduğu bildirilmiştir (40).

Gen ekspresyonu: Moleküler biyoloji alanında yapılan çalışmalar, miRNA'lerin tümör oluşumunda ve tümör gelişiminde önemli bir rol oynadığını göstermiştir. Bir miRNA, kanserin gen aktivitesini bir tümör süpresörü olarak azaltarak ve aynı zamanda kanser geni olarak gen aktivitesini azaltarak, tümör ile ilişkili genlerin ekspresyonunu düzenleyebilir. U87 glioma hücreleri üzerine mangiferinin etkisinin incelendiği bir araştırmada, miR-15b’nin indüksiyonu ve MMP-9 ekspresyonunun inhibisyonu ile glioma hücrelerinde proliferasyonu ve apoptozu düzenlediği gösterilmiştir (41). Östrojen reseptör alfa (ERa) ve beta (ER $\beta)$ meme kanserinden sorumlu gen transkripsiyonunun iki regülatörüdür. Mango bileşenlerinden kuarsetin, mangiferin ve norathyriol, östrojen reseptörünün her iki izoformunu aktive etme yeteneğini incelendiği bir çalışmada, kuarsetin ve norathyriol, meme kanseri hücrelerinin (MCF-7) canlılığını azaltırken, mangiferinin MCF-7 hücreleri üzerinde herhangi bir etkisi olmamıştır (42).

\section{Kemoterapötik İlaçlar ve Mangiferin Etkileşimi}

Mangiferin, kanserli hücrelerin hücre ölümlerini seçici olarak hedefleme ve sağlıklı hücrelerin hayatta kalmasını arttırma potansiyeline sahiptir. Mangiferin, mevcut ilaçlarla birlikte kullanıldığında, NFkB aktivitesinin modülasyonu yoluyla hücre ölümünü güçlendirebilir ve $\mathrm{G}_{2} / \mathrm{M}$ kontrol noktasındaki kanserli hücrelerde hücre döngüsünün durmasına neden olabilir ve hücreleri etoposid gibi kemoterapötik ajanların neden olduğu apoptozise duyarlı bırakabilir. NFאB inhibisyonu ile mangiferinin kanser hücrelerindeki kemoterapötik ajanlara karşı direnci azalttığı düşünülmektedir. Proto-apoptotik ajanlar (oksaliplatin, etoposid, doksorubisin ve paklitaksel) kullanarak yapılan çalışmalar mangiferin ile birlikte uygulandığında ek yararlı etkileri olduğunu göstermektedir (6). Yapılan bir çalışmada oksaliplatin ile tedavi edilen kolon kanseri hücrelerine (HT29) $10 \mu \mathrm{g} / \mathrm{mL}$ mangiferin eklemesi yapılmış, kaspaz-3 aktivasyonunda artma ve DNA parçalanması ve hücre döngüsünün S fazında bir gecikme gerçekleşmiştir. Mangiferinin oksaliplatine dirençli HT29 hücrelerinde NF- $\kappa B$ aktivasyonunda bir azalmaya neden olduğu gösterilmiştir (43). Yapılan bir başka çalışmada da, mangiferinin, in vitro HL-60 lösemi hücrelerinin etoposidine duyarlılığını azaltmaksızın, oksidatif stresini azaltan ve normal hücreleri koruyan yeni bir Nrf2 aktivatörü olduğu ve potansiyel bir kemoterapi adjuvanı olabileceği bildirilmiştir (44). Mangiferin gibi antioksidanların kanser tedavisinde kullanımına ilgi giderek artmaktadır.

Ancak, kanser hücreleri üzerinde antioksidanların etkileri hala tartışılmalıdır. Yapılan çalışmalarda standart tedavi ile birlikte yüksek doz antioksidan alımının seçici olarak kanser hücrelerini öldürmesine rağmen, düşük doz antioksidanların kanser hücrelerinin proliferasyonu artırdığı, radyasyon ve kemoterapötik tedavinin etkinliğini azalttı̆̆ saptanmıştır. $\mathrm{Bu}$ nedenle geleneksel tıpta yaygin olarak kullanılan her bir fitoterapotik ajanın, hastalıktan korunmada ya da kanser gibi kronik hastalıkların tedavisinde kullanılacak dozları klinik çalışmalarla belirlendikten sonra, hedefe yönelik olarak kullanılmalıdır (45). Mangiferinin klinik çalışmalarla belirlenmiş, Gıda ve İlaç Dairesi (FDA) nin ve Avrupa Gıda Güvenliği Otoritesi (EFSA) nin önerdiği standart bir dozu bulunmamaktadır. 


\section{Mangiferinin Biyoyararlılığı}

Çalışmalarda mangiferinin oral biyoyararlılığının çok düşük olduğu bildirilmiştir (46-48). Gastrointestinal sistemden emilebildiği, karaciğerdeki metabolizmasında sinırlllılar olabileceğini düşünülmektedir (47). Ayrıca, biyoyararlılığının zayıf olması, membran geçirgenliğinin az olması, mangiferin metabolizmasina enzimler veya entrobakteriler tarafından aracılık edilmesi, permeabilite-glikoproteinden etkilenmesinden kaynaklanabilir. Oral mangiferin dozunda bir ya da üç kat artış, sıçanlarda sistemik maruziyetinin sadece $\% 25$ ve \%60 oranına karşılık gelen artışa neden olmaktadır. Bu durum güçlü bir fitokimyasal olarak bilinmesine rağmen, olumlu farmakolojik özelliklerinin aydınlatılmasında büyük bir engel oluşturmaktadır (48). Mangiferinin metabolitlerinin de, mangiferinin farmakolojik aktivitelerini tamamen veya kısmen etkileyebileceği düşünülmektedir. Mangiferinin vücuttaki etki mekanizmasını anlaşlabilmesi için, gelecekteki çalışmalarda metabolitlerinin tanımlanması yararlı olacaktır.

\section{Mangiferinin Toksisitesi}

Mangiferin polifenolik yapısından dolayı etkin bir serbest radikal temizleme aktivitesine sahiptir, ancak serbest radikallerin normal hücresel homeostaz için gerekliliği toksisiteyi daha karmaşık bir konu haline getirmektedir. Yüksek düzeyde bu antioksidan moleküllerin, hücre içi mitokondriyal solunum zincirinde ciddi hasara neden olabileceği düşünülmektedir. Ancak pek çok çalışma, Mangiferinin hiç veya önemsiz toksisite gösterdiğini rapor etmiştir. Ayrıca mango meyvesindeki içeriğin hücresel işleyişi iyileştirmek için güvenli ve yararlı olduğu bulunmuştur (18). Yirmi bir sağlıklı insan üzerinde yapılan bir çalışmada $0.9 \mathrm{~g}$ mangiferinin oral kullanımı güvenli bulunmuştur (46). In vivo bir çalışmada ise, mangiferinin sadece yüksek düzeyde $(200 \mu \mathrm{g} / \mathrm{mL})$ hafif DNA hasarına yol açtığı bildirilmiştir (40). Bununla birlikte, toksisitesini veya güvenli miktarını değerlendirmek için daha fazla farmakokinetik, farmakodinamik ve klinik araştırmalara gerek duyulmaktadır.

\section{SONUÇ VE ÖNERİLER}

Mangiferinin anti-kanser özellikleri son yıllarda kapsamlı bir şekilde incelenmektedir. Vücudu oksidatif stresle ilişkili hasarlara karşı koruduğu, bununla birlikte, kanser immün tedavisi için immünomodülatör ve gen düzenleyici etkilere (genel olarak NF-кB üzerinde) sahip olduğu bildirilmiştir. Pek çok çalışma, mangiferinin hiç veya önemsiz toksisite gösterdiğini rapor etmiş ve mangiferini gelecekteki kanser tedavileri için güçlü bir aday olarak göstermiştir. Ancak, çalışmalarda oral biyoyararlılığının çok düşük olduğu bildirilmiş ve etkileri üzerine bildirilen çalışmalar ağırlıklı olarak hücre kültürlerinde ve kemirgenlerde yürütülmüştür. Mangiferinin daha iyi anlaşılabilmesi için insanlarda daha fazla klinik çalışmaya gerek vardır.

Çıkar çatışması - Conflict of interest: Yazarlar çıkar çatışması olmadığın beyan ederler. - The authors declare that they have no conflict of interest.

\section{KAYNAKLAR}

1. American Cancer Society. Cancer Facts \& Figures 2015. Atlanta, GA: American Cancer Society. https:// www.cancer.org/content/dam/cancer-org/research/ cancer-facts-and-statistics/annual-cancer-factsand-figures/2015/cancer-facts-and-figures-2015.pdf. Accessed June 24, 2015.

2. Torre L, Bray F, Siegel R, Ferlay J, Lortet-Tieulent J, Jemal A. Global cancer statistics 2012. Cancer J. Clin. 2015;65:87-108.

3. Weng CJ, Yen GC. Chemopreventive effects of dietary phytochemicals against cancer invasion and metastasis: Phenolic acids, monophenol, polyphenol, and their derivatives. Cancer Treat Rev. 2012; 38(1):76-87.

4. Lee JH, Khor TO, Shu L, Su ZY, Fuentes F, Kong AN. Dietary phytochemicals and cancer prevention: Nrf2 signaling, epigenetics, and cell death mechanisms in blocking cancer initiation and prgression. Pharmacol Ther. 2013;137(2):153-71.

5. Shah KA, Patel MB, Patel RJ, Parmar PK. Mangifera Indica (Mango) Pharmacogn Rev. 2010;4(7):42-8. 
6. Gold-Smith F, Fernandez A, Bishop K. Mangiferin and Cancer: Mechanisms of Action. Nutrients 2016;8:396.

7. Rivera DG, Hernandez I, Merinos N, Luque Y, Alvarez A, Martin Y, et al. Mangifera indica L. extract (Vimang) and Mangiferin reduce the airway inflammation and Th2 cytokines in murine model of allergic asthma. J Pharm Pharmacol. 2011;63(10):1336-45.

8. Ganogpichayagrai A, Palanuvej C, Ruangrungsi N. Antidiabetic and anticancer activities of Mangifera indica cv. Okrong leaves. J Adv Pharm Technol Res 2017;8(1): 19-24.

9. Singh AK, Raj V, Keshari AK, Rai A, Kumar P, Rawat $\mathrm{A}$, et al. Isolated Mangiferin and naringenin exert antidiabetic effect via PPAR $\gamma /$ GLUT4 dual agonistic action with strong metabolic regulation. Chem Biol Interact 2018;280:33-44.

10. Wang H, Zhu YY, Wang L, Teng T, Zhou M, Wang SG, et al. Mangiferin ameliorates fatty liver via modulation of autophagy and inflammation in high-fat-diet induced mice. Biomed Pharmacother 2017;96:328-35.

11. Sandoval-Gallegos EM, Ramírez-Moreno E, Lucio JG, Arias-Rico J, Cruz-Cansino N, Ortiz MI, Cariño-Cortés R. In vitro bioaccessibility and effect of Mangifera indica (Ataulfo) leaf extract on induced dyslipidemia. J Med Food 2018;21(1):47-56.

12. Ishida M, Sasaki T, Nishi K, Tamamoto $T$, Sugahara T. Suppressive effect of ethanol extract from mango (Mangifera indica L.) peel on IgE production in vitro and in vivo. Biosci Biotechnol Biochem 2018;3:1-8.

13. Núñez Sellés AJ, Dagila M, Rastrelli L. The potential role of Mangiferin in cancer treatment through its immunomodulatory, anti-angiogenic, apoptopic, and gene regulatory effects. Biofactors. 2016;42(5):475-91.

14. Imran M, Arshad MS, Butt MS, Kwon JH, Arshad MU and Sultan MT. Mangiferin: a natural miracle bioactive compound against lifestyle related disorders. Lipids Health Dis. 2017;16(1):84.

15. Singh SK, Sharma VK, Kumar Y, Sadish Kumar S, Sinha SK. Phytochemical and pharmacological investigations on Mangiferin. Herbapolonica 2009;55(1):126-39.

16. Matkowski A, Kuś P, Góralska E, Woźniak D. Mangiferin - a bioactive xanthonoid, not only from mango and not just antioxidant. Mini Rev Med Chem 2013;13(3):439-55.

17. Masibo M, He Q. Major mango polyphenols and their potential significance to human health. CRFSFS. 2008;7(4):309-19.

18. Saha S, Sadhukhan P, Sil PC. Mangiferin: A xanthonoid with multipotent anti-inflammatory potential. BioFactors 2016;42(5):459-74.

19. Rajendran P, Rengarajan T, Nandakumar N, Divya H, Nishigaki I. Mangiferin in cancer chemoprevention and treatment: pharmacokinetics and molecular targets. J Recept Signal Transduct Res. 2015;35(1):76-84.
20. Mutlu Altundağ E, Yılmaz AM, Koçtürk S, Taga Y, Yalçın AS. Synergistic induction of apoptosis by quercetin and curcumin in chronic myeloid leukemia (K562) cells. Nutr Cancer 2018;70(1):97-108.

21. Mehmood T, Maryam A, Tian X, Khan M, Ma T. Santamarine inhibits NF-кB and STAT3 activation and induces apoptosis in $\mathrm{HepG}_{2}$ liver cancer cells via oxidative stress. J Cancer 2017;8(18):3707-17.

22. Sahoo BK, Zaidi AH, Gupta P, Mokhamatam RB, Raviprakash N, Mahali SK, et al. A natural xanthone increases catalase activity but decreases NF-kappa B and lipid peroxidation in U-937 and $\mathrm{HepG}_{2}$ cell lines. Eur J Pharmacol 2015;764:520-8.

23. Takeda T, Tsubaki M, Kino T, Yamagishi M, Iida M, Itoh $\mathrm{T}$, et al. Mangiferin induces apoptosis in multiple myeloma cell lines by suppressing the activation of nuclear factor kappa B-inducing kinase. Chem Biol Interact. 2016;251:26-33.

24. Zhang QJ, Yue L. Inhibitory activity of mangiferin on Helicobacter pylori-induced inflammation in human gastric carcinoma Ags cells. Afr J Tradit Complement Altern Med 2017;14(1):263-71.

25. Shi W, Deng J, Tong R, Yang Y, He X, Lv J, et al. Molecular mechanisms underlying Mangiferin-induced apoptosis and cell cycle arrest in A549 human lung carcinoma cells. Mol Med Rep. 2016;13:3423-32.

26. Li J, Malakhova M, Mottamal M, Reddy K, Kurinov I, Carper A, et al. Norathyriol suppresses solar UVinduced skin cancer by targeting ERKs. Cancer Res 2012;72(1):260-70.

27. Li M, Ma H, Yang L, Li P. Mangiferin inhibition of proliferation and induction of apoptosis in human prostate cancer cells is correlated with downregulation of B-cell lymphoma-2 and upregulation of microRNA-182. Oncol Lett. 2016;11: 817-22.

28. Cuccioloni M, Bonfili L, Mozzicafreddo M, Cecarini V, Scuri S, Cocchioni M, et al. Mangiferin blocks proliferation and induces apoptosis of breast cancer cells via suppression of the mevalonate pathway and by proteasome inhibition. Food Funct 2016 ;7(10):4299-309.

29. Li H, Huang J, Yang B, Xiang T, Yin X, Peng W, et al. Mangiferin exerts antitumor activity in breast cancer cells by regulating matrix metalloproteinases, epithelial to mesenchymal transition, and $\beta$ catenin signaling pathway. Toxicol. Appl. Pharmacol 2013;272:180-90.

30. Artavanis-Tsakonas S, Rand MD, Lake RJ. Notch signaling: cell fate control and signal integration in development. Science 1999;284(5415):770-6.

31. Zou B, Wang H, Liu Y, Qi P, Lei T, Sun M, et al. Mangiferin induces apoptosis in human ovarian adenocarcinoma OVCAR3 cells via the regulation of Notch3. Oncol Rep 2017;38(3):1431-41. 
32. Peng ZG, Luo J, Xia LH, Chen Y, Song SJ. CML cell line K562 cell apoptosis induced by Mangiferin. Zhongguo Shi Yan Xue Ye Xue Za Zhi 2004;12(5):590-4.

33. Shoji K, Tsubaki M, Yamazoe Y, Satou T, Itoh T, Kidera Y, et al. Mangiferin induces apoptosis by suppressing Bcl$\mathrm{xL}$ and XIAP expressions and nuclear entry of NF- $\mathrm{KB}$ in HL-60 cells. Arch Pharm Res. 2011;34(3):469-75.

34. Barreto JC, Trevisan MT, Hull WE, Erben G, de Brito ES, Pfundstein B, et al. Characterization and quantitation of polyphenolic compounds in bark, kernel, leaves, and peel of mango (Mangifera indica L.). J Agric Food Chem 2008;56(14):5599-610.

35. Luo F, Lv Q, Zhao Y, Hu G, Huang G, Zhang J, et al. Quantification and purification of Mangiferin from Chinese Mango (Mangifera indica L.) cultivars and its protective effect on human umbilical vein endothelial cells under $\mathrm{H}(2) \mathrm{O}(2)$-induced stress. Int J Mol Sci. 2012;13(9):11260-74.

36. Das S, Nageshwar Rao B, Satish Rao BS. Mangiferin attenuates methylmercury induced cytotoxicity against IMR-32, human neuroblastoma cells by the inhibition of oxidative stress and free radical scavenging potential. Chem Biol Interact 2011;193(2):129-40.

37. Agarwala S, Rao B N, Mudholkar K, Bhuwania R, Rao BSS. Mangiferin, a dietary xanthone protects against mercury-induced toxicity in $\mathrm{HepG}_{2}$ cells. Inc. Environ Toxicol 2012;27:117-27.

38. Khurana RK, Kaur R, Lohan S, Singh KK, Singh B. Mangiferin: a promising anticancer bioactive. Pharm Pat Anal 2016;5(3):169-81.

39. Zhang B, Zhao J, Li S, Zeng L, Chen Y, Fang J. Mangiferin activates the Nrf2-ARE pathway and reduces etoposideinduced DNA damage in human umbilical cord mononuclear blood cells. Pharm Biol. 2015;53(4):503-11.

40. Rodeiro I, Delgado R, Garrido G. Effects of a Mangifera indica L. stem bark extract and Mangiferin on radiationinduced DNA damage in human lymphocytes and lymphoblastoid cells. Cell Prolif 2014;47(1):48-55.

41. Xiao J, Liu L, Zhong Z, Xiao C, Zhang J. Mangiferin regulates proliferation and apoptosis in glioma cells by induction of microRNA-15b and inhibition of MMP-9 expression. Oncol Rep 2015;33(6):2815-20.

42. Wilkinson AS, Taing MW, Pierson JT, Lin CN, Dietzgen RG, Shaw PN, et al. Estrogen modulation properties of Mangiferin and quercetin and the Mangiferin metabolite norathyriol. Food Funct 2015;6(6):1847-54.

43. du Plessis-Stoman D, du Preez J, Van de Venter M . Combination treatment with oxaliplatin and Mangiferin causes increased apoptosis and downregulation of NFKB in cancer cell lines. Afr J Tradit Complement Altern Med. 2011;8(2):177-84.

44. Zhang BP, Zhao J, Li SS, Yang LJ, Zeng LL, Chen Y, et al. Mangiferin activates Nrf2-antioxidant response element signaling without reducing the sensitivity to etoposide of human myeloid leukemia cells in vitro. Acta Pharmacol Sin. 2014;35(2):257-66.

45. Koçyiğit A, Selek Ş. Eksojen antioksidanlar iki yönü keskin kılıçlardır. Bezmialem Science 2016;2:70-5.

46. Han D, Chen C, Zhang C, Zhang Y, Tang X. Determination of mangiferin in rat plasma by liquid-liquid extraction with UPLC-MS/MS. J Pharm Biomed Anal. 2010; 1(1):260-63.

47. Hou S, Wang F, Li Y, Li Y, Wang M, Sun D, et al. Pharmacokinetic study of Mangiferin in human plasma after oral administration. Food Chem. 2012;132(1):28994.

48. Tian X, Xu Z, Li Z, Ma Y, Lian S, Guo X, et al. Pharmacokinetics of mangiferin and its metabolitenorathyriol, Part 2: Influence of UGT, CYP450, P-gp, and enterobacteria and the potential interaction in Rhizoma Anemarrhenae decoction with timosaponin $\mathrm{B}_{2}$ as the major contributor. Biofactors. 2016;42(5):545-55. 